UDC 504.349

Vasil M. Trysnyuk, D. S., Senior Research Associate

ORCID ID: 0000-0001-9920-4879e-mail:trysnyuk@ukr.net

Institute of Telecommunication and Global Information Space of NASU, Kyiv, Ukraine

\title{
ECOLOGICAL SAFETY OF TERRITORIES AT INTRODUCTION OF MODERN TECHNOLOGIES OF PROCESSING OF VEGETABLE WASTES
}

\begin{abstract}
Annotation. Work is devoted to the decision of research and practice task from the ground of changes of the state of ecological safety of territories at introduction of modern technologies of processing of vegetable wastes. The worked out practical recommendations are in relation to reduction of negative influence on the environment of vegetable wastes that is passed for introduction in further activity in relation to providing of ecological safety of territories.

Key words: ecological safety of territory; vegetable wastes; treatment vegetable wastes.
\end{abstract}

\section{Introduction}

Providing ecologically and technically safe terms of vital functions of society attributed to priority national interests, because a present ecological situation in Ukraine is characterize as difficult.

The feature of the ecological state in Ukraine is that ecologically sharp local situations become complicate by regional crises with her protracted medicobiological, economic, ecological and social consequences. Relations in relation to providing of ecological safety closely constrained with the rational and effective use of natural resources, with the use of ecologically dangerous territories and objects that stipulates the complexity of maintenance of concept of ecological safety. That includes for itself, the guard of natural environment: a) the certain state of natural object (safety of nature) and b) system of guarantees of the state to the citizens on providing of normal vital functions of human.

The decision of problem of providing of ecological safety of territory at introduction of modern technologies of processing of vegetable wastes is in the first turn related to the choice of general conception of further development of the state.

\section{Analysis of previous researches and publications}

Analyzing the modern state of ecological safety of territories and handling wastes of production and consumption it is possible to assert that: design of changes of the state of ecological safety, what would take into account quality of environment and condition of residence, their influence on mean time of life is not would prove to practical application. Such Ukrainian and foreign scientists and practices did a ponderable contribution to research of problems of ecological safety of the inhabited territories: Adamenko O.M., Bilyavskiy G.O., Babyak O.S., Iliin O.J., Drawn M.C., Safronov T.A., Ushakov E.P. 


\section{Basic part}

Existent procedures of evaluation of the state of ecosystem of any region of settlement at building or reconstruction of industrial enterprises are took to verification of the possible exceeding maximum of possible concentrations of toxic substances in up casts and extras of enterprise.

The ecological constituent of steady development of countries is estimated by means of the known index of ESI (Environmental Sustainability Index is an index of ecological constancy, first presented in 2001 in Davos), offered by Center on an ecolaw and politics of Yale University (USA). It is form from a 21 ecological indicator that in turn settled accounts based on the use 76 sets of ecological data:

- about the state of natural resources in a country,

- levels of contamination of environment in the past and today,

- efforts of country in relation to a management,

- possibility of country to improve ecological descriptions and others like that, the ecological state [1].

System of ecology of management has fully certain differences from the system of ecology of production. Under an ecology, managements understand the process of steady and successive introduction of the systems of technological, administrative and other decisions that allow to promote efficiency of the use of natural resources and terms equally with an improvement or even maintenance of quality of natural environment (or in general vital environment) on local, regional and global levels.

Under the system, a management understands element of organizational structure in that the systems of financing, planning, and control are included after producing of products, account, grant of services and others like that. A main problem in organization of control system consists in the exposure of measure of accordance of existent factors of the systems of strategy of development of object, with those that is set.

At conducting a ranking of methods of utilization and processing of wastes of phytogenous on results there in flounce on a natural environment, mark results (table 1).

Table 1 - Results of ranging of methods of processing of vegetable wastes are on results influence on an environment

\begin{tabular}{|c|l|l|}
\hline № & $\begin{array}{l}\text { Name of method of } \\
\text { processing of vegetable } \\
\text { wastes }\end{array}$ & $\begin{array}{l}\text { Consequences of influence of method of processing of } \\
\text { vegetable wastes are on ecological safety of territory }\end{array}$ \\
\hline 1 & \multicolumn{1}{|c|}{2} & \multicolumn{1}{|c|}{3} \\
\hline 1 & $\begin{array}{l}\text { Sorting of organic } \\
\text { wastes of phytogenous }\end{array}$ & $\begin{array}{l}\text { Harmful effect on a natural environment on the whole and } \\
\text { on a health man in particular minimized during a } \\
\text { simultaneous exception potentially of dangerous and } \\
\text { harmful components }\end{array}$ \\
\hline 2 & $\begin{array}{l}\text { Destruction of } \\
\text { vegetable wastes is in a } \\
\text { catalytic environment }\end{array}$ & $\begin{array}{l}\text { The extras of hazardous substances considerably below than } \\
\text { maximum possible concentrations }\end{array}$ \\
\hline 3 & $\begin{array}{l}\text { Anaerobic fermentation } \\
\text { is with a receipt and } \\
\text { utilization of biogas }\end{array}$ & $\begin{array}{l}\text { Harmful effect of biogas on the environment and human } \\
\text { health depends on his concentration in atmospheric air and } \\
\text { sentinel period of breathing in this product }\end{array}$ \\
\hline
\end{tabular}


Table 1 continuation

\begin{tabular}{|c|l|l|}
\hline 1 & \multicolumn{1}{|c|}{2} & \multicolumn{1}{c|}{3} \\
\hline 4 & Punching & $\begin{array}{l}\text { Contamination of objects of hydrosphere and fertile } \\
\text { epiphaseofsial hazard - to soil, incomplete taking into } \\
\text { account of properties, composition and state headstock }\end{array}$ \\
\hline 5 & $\begin{array}{l}\text { Method of heat } \\
\text { treatment of vegetable } \\
\text { wastes to incinerations }\end{array}$ & $\begin{array}{l}\text { Contamination of atmosphere hazard with high probability } \\
\text { of further contamination of objects of hydrosphere and soil, } \\
\text { exceeding maximum of possible norms of extras of } \\
\text { carcinogenic dioxins and furan. Elimination of valuable } \\
\text { components, high exit of ash and slags, incomplete taking } \\
\text { into account of properties, composition and state of } \\
\text { feedstock, decline of immunity of population and animals } \\
\text { that live in a radius 30-50 kilometers, high maintenance of } \\
\text { dioxin in pectoral milk of mothers; complication of } \\
\text { stabilizing of process of incineration. }\end{array}$ \\
\hline
\end{tabular}

The results of the conducted procedure of ranking witnessed that most dangerous for a natural environment on the whole and for the health of population of territory there is a method of heat treatment of vegetable wastes by means of incineration. The friendliest to the environment and health of population are two methods. Method of sorting of wastes with a simultaneous exception as potentially dangerous so valuable components and method of destruction of organic wastes of phytogenous in a catalytic environment [2].

For realization of effective management of territory ecological safety the map-chart of distribution of areas of Ukraine is use after ecological strength security (fig. 1).

One of dangerous for an environment and health of humanity of problems there is an accumulation of various wastes in the process of vital functions and productive activity of man that in the whole world grows rates that pass a head their processing, disinfestation and utilization.

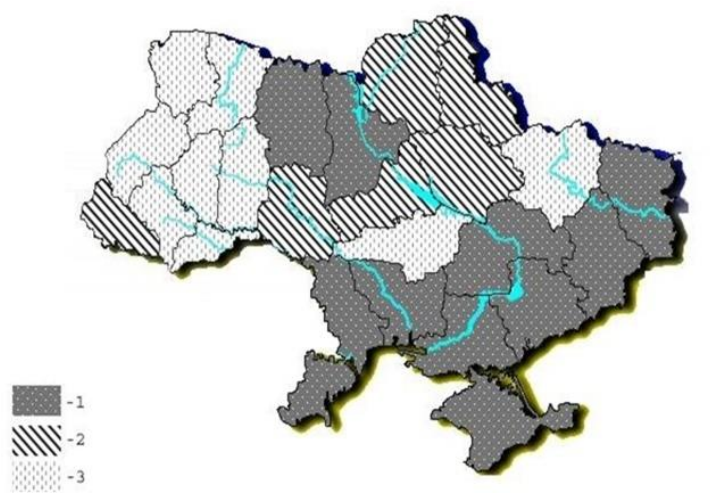

Fig. 1 - Map chart of distribution of territories of Ukraine after administrative distribution for to ecological strength of territories securities in obedience to the conducted calculations for 2015: 1 - crisis, 2 - передкризовий, 3 - normal

Thus, to provide acceptable to quality life of society and steady development of territories ecological strength security and to decrease negative in fluency of wastes on a natural environment overall and on the state of health of population in particular, 
it is necessary to develop new technologies in industry of handling wastes or to perfect already existing.

Wastes of consumption or hard domestic wastes have various morphological composition. In composition contained on the average 30 organic wastes of phytogenous [3].

Results of conducted ranking of methods of processing of vegetable wastes, witnessed that the most favorable in ecological sense methods of processing and utilization of vegetable wastes are two methods. Sorting with the simultaneous exception of components, that can threaten to both the health of population and environment on the whole and destruction of organic wastes of phytogenous in a catalytic environment. Leaning on the results of conducted ranking of methods of processing of vegetable wastes after the degree of their influence on a natural environment, offered recommendations in relation to reduction of negative influence of vegetable wastes on ecological safety of territories of compact residence of population.

Based on undertaken scientific studies research and practice recommendations are work out in relation to the evaluation of changes of the state of ecological safety of territories at introduction of modern technologies of processing of vegetable wastes.

At prognostication of indexes of ecological safety of the inhabited territory, it is needed to apply the procedure, based on Bayes' theorem taking into account the complex of indexes that characterize the state of ecological situation and totality of parameters of natural environment.

During realization of the activity related to handling organic wastes of phytogenous, it is expedient to apply reasonable methodology of ranking of the prearranged methods of utilization of wastes on the indexes of negative influence on a natural environment overall and on a health population that lives on concrete territory.

The worked out technological analysis of organic wastes of phytogenous taking into account factious composition of plant it is expedient to use for determination of method of processing of concrete part of plant and application of finish good domain from her.

To promote ecological strength of territory of compact residence of population security during handling vegetable wastes it is necessary by means of combination of method of sorting of wastes with a simultaneous exception from them both ecologically dangerous and valuable components, destructions of these wastes in a catalytic environment and also method of their processing on one territory.

\section{Conclusions}

For prognostication of indexes of ecological safety of territory at handling vegetable wastes, the modified procedure based on the use of Bayes' theorem is involved. Authentication of dynamics of changes of her indexes is take to the analysis of supervisions and comparison of results.

The distribution of areas of Ukraine evidently represented on a map-chart on three groups after ecological strength security is use for realization of effective management of the inhabited territories ecological safety at handling wastes of phytogenous. 


\section{REFERENCES}

1. Ecology of Gusyatin district. Monograph / V.M. Trysnuk // Ternopil, Ternograph, 2004. 219.

2. Ecological safety of techno-natural geosystems of region / V.M. Trysnuk, O.M. Trofimchuk, T.V. Trysnuk // Announcer Vinnytsya polytechnic institute. - Vinnytsya, 2015 - №5 (122). 30-34.

3. Monitoring of places of formation, storage and moving away of wastes is for the design of changes of the state of ecological safety of city. M.M. Lebedev, K.E. Muhina - 2008, № 3-4. 54-56.

Text of the article was accepted by Editorial Team 17.01.2018

\section{В.М. Триснюк}

\section{ЕКОЛОГІЧНА БЕЗПЕКА ТЕРИТОРІЙ ПРИ ВПРОВАДЖЕННІ СУЧАСНИХ ТЕХНОЛОГІЙ ПЕРЕРОБКИ РОСЛИННИХ ВІДХОДІВ}

Анотація. Робота присвячена вирішенню науково-практичної задачі на підставі змін стану екологічної безпеки територій при впровадженні сучасних технологій переробки рослинних відходів. Розроблені практичні рекомендації стосовно зменшення негативного впливу на навколишнє середовище рослинних відходів, що передаються для впровадження у подальшу діяльність щодо забезпечення екологічної безпеки територій.

Ключові слова: екологічна безпека території; рослинні відходи; обробка рослинних відходів.

Автор (науковий ступінь, вчене звання, посада):

\section{Триснюк Василь Миколайович}

доктор технічних наук, старший науковий співробітник

Інститут телекомунікацій і глобального інформаційного простору НАН України

Адреса робоча: 03186 Україна, м. Київ, Чоколівський бульвар, 13

ORCID ID: 0000-0001-9920-4879e-mail:trysnyuk@ukr.net 